\title{
Assessment of Noise Levels in Primary and Secondary Schools in Nnewi, Anambra State
}

\author{
Ogochukwu M. T. B. Ochiabuto ${ }^{1}$, Isaiah C. Abonyi ${ }^{2}$, Rebecca N. Ofili ${ }^{2}$, Onyinye S. Obiagwu ${ }^{2}$, Alison O. Ede ${ }^{2 *}$, \\ Monique Okeke ${ }^{2}$, Peter M. Eze ${ }^{2}$
}

\begin{abstract}
${ }^{1}$ Department of Medical Laboratory Science, Faculty of Health Sciences and Technology, Nnamdi Azikiwe University, Nnewi campus, Anambra State, NIGERIA ${ }^{2}$ Department of Environmental Health Science, Faculty of Health Sciences and Technology, Nnamdi Azikiwe University, Nnewi campus, Anambra State, NIGERIA *Corresponding Author: edeokorie@gmail.com
\end{abstract}

Citation: Ochiabuto, O. M. T. B., Abonyi, I. C., Ofili, R. N., Obiagwu, O. S., Ede, A. O., Okeke, M. and Eze, P. M. (2021). Assessment of Noise Levels in Primary and Secondary Schools in Nnewi, Anambra State. European Journal of Environment and Public Health, 5(1), em0054. https://doi.org/10.29333/ejeph/8425

\section{ARTICLE INFO}

Received: 12 May 2020

Accepted: 27 Jun. 2020

\begin{abstract}
This study was conducted basically to evaluate the noise $\mathrm{dB}(\mathrm{A})$ levels in primary and secondary schools within Otolo area of Nnewi, Anambra State, Nigeria. A total of eight (8) randomly selected schools (four primary and four secondary schools) were assessed. Noise levels in the classrooms and school playgrounds of the schools were measured using a factory-calibrated sound level meter. Results of this study revealed that the noise levels of classrooms and playgrounds of the schools selected for this study were in the range of 78-92 $\mathrm{dB}(\mathrm{A})$ and 61-97 $\mathrm{dB}(\mathrm{A})$ respectively. These levels were significantly above the World Health Organization's recommended classroom and outdoor/playground noise levels. This study creates awareness on the implications of noise in schools and learning centers, and also promotes a simple method for regular assessment of the noise levels in these environments.
\end{abstract}

Keywords: noise, school, Nnewi, Anambra State

\section{INTRODUCTION}

The school is important for the cognitive, creative, and social development of children, and is therefore expected to ensure the best possible conditions for a child's physical and intellectual development, including control of excess environmental noise (Ana et al., 2009).

Children are however exposed to many different types of noise while at school. A wide range of noise levels have been measured inside schools, with levels varying significantly between different types of space and different classroom activities (Bridget and Julie, 2003). For much of the day in a primary school classroom, young children are exposed to the noise of other children producing "classroom babble" at levels typically of around 65 decibels $[\mathrm{dB}(\mathrm{A})]$ level, while the typical overall exposure level of a child at primary school has been estimated at around $72 \mathrm{~dB}(\mathrm{~A})$ (Shield and Dockrell, 2004, 2008).

Generally, noise has adverse impact on the physical, social and psychological wellbeing (Ibekwe et al., 2016). High noise levels in the school environment pose a real public health problem. Exposure for more than six hours a day to sound in excess of $85 \mathrm{~dB}(\mathrm{~A})$ is potentially hazardous to health (Ana et al., 2009). It is also generally accepted that all types of noise exposure at school affect children's learning and academic performance (Shield and Dockrell, 2004, 2008).

To be able to hear and understand spoken messages in classrooms, the World Health Organization (WHO) recommends that in school classrooms and pre-schools, the background sound level should not exceed $35 \mathrm{~dB}(\mathrm{~A})$ during teaching sessions. Also, school outdoor/playground noise level should not exceed $55 \mathrm{~dB}(\mathrm{~A})$, the same value given for outdoor residential areas in daytime (Berglund et al., 1999).

There are several national and international guidelines relating to the acoustics of classrooms. These mainly take the form of recommended values for reverberation time and background noise levels in teaching spaces, together with sound insulation requirements for schools (Bridget and Julie, 2003). For example, the United States American National Standards Institute (ANSI) sets out guideline values for noise levels, reverberation times, and sound insulation in schools. Also, in England and Wales, school buildings must comply with the Building Regulations (Shield and Dockrell, 2004, 2008).

In Nigeria, for example, the National Environmental Standards and Regulations Enforcement Agency's (NESREA) maximum permissible noise level specification for the general 
- Nneoma Memorial Primary School

n Christ the King International
- Holy Innocent Primary School

- UNIZIK Nursery/Primary School

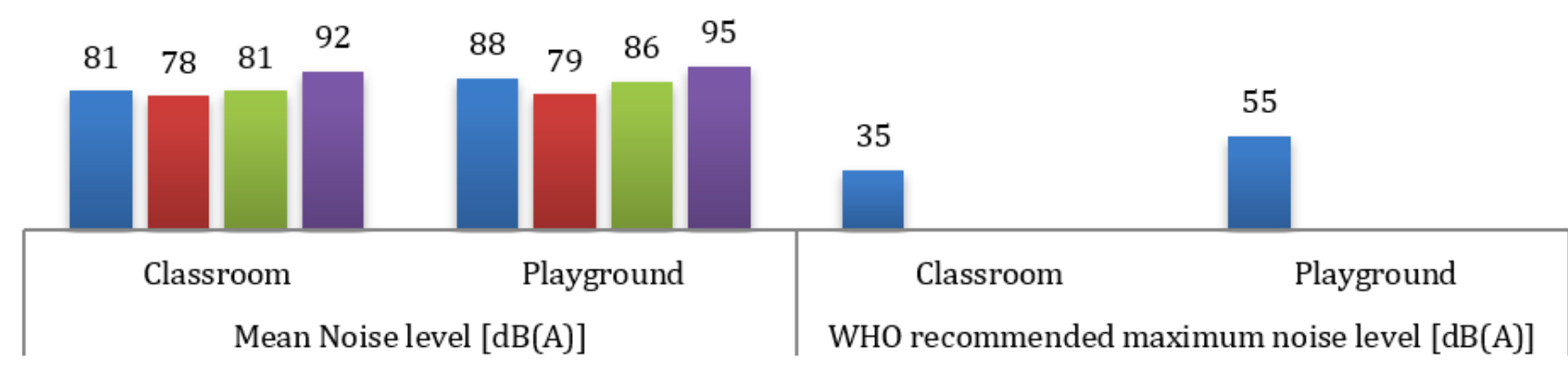

Figure 1. Mean Noise levels $[(\mathrm{db}) \mathrm{A}]$ of classrooms and playgrounds of the selected primary schools in Otolo-Nnewi

environment such as buildings used as hospital, convalescence home, home for the aged, sanatorium, institutes of higher learning, conference rooms, public library, environmental or recreational sites is $45 \mathrm{~dB}(\mathrm{~A})$ (NESREA, 2009). Despite these specifications, many children in Nigeria do not have access to ideal or serene learning environments (Ana et al., 2009). Despite the proven significance of noise exposure at school, the number of schools affected by noise from diverse sources is unknown and there is relatively little data available on typical noise levels inside and outside schools (Shield and Dockrell, 2004). Therefore, this study was conducted basically to determine the noise $\mathrm{dB}(\mathrm{A})$ levels in primary and secondary schools within Otolo area of Nnewi, Anambra State, Nigeria.

\section{MATERIALS AND METHODS}

\section{Study Area}

This study was carried out in selected primary and secondary schools located in Otolo, Nnewi, Anambra State. Nnewi is a metropolitan city in Nnewi-North Local Government Area (LGA) and is the second largest city in Anambra State in southeastern Nigeria. It comprises four autonomous villages: Otolo, Uruagu, Umudim, and Nnewichi (Elufioye, 2017). Nnewi is a one town LGA that has an area dimension of $72 \mathrm{~km}^{2}$ and an approximate total population of 391,222 people with a sex ratio of 1:2 male: female (Nnebue et al., 2016).

\section{Study Location, Sample Size and Sampling Technique}

A total of eight (8) randomly selected schools (four primary and four secondary schools) in the Otolo-Nnewi area were assessed. The primary schools include: Nneoma Memorial Primary School, Holy Innocent Primary School, Christ the King International, and UNIZIK Nursery/Primary School. The secondary schools were: Good Shepherd Secondary School, Maria Regina Comprehensive Secondary School, St. Joseph's Secondary School, and St. Philip's Anglican Grammar School.

\section{Measurement of Noise Levels}

Noise levels in the schools were measured using a factorycalibrated BENETECH Model GM 1357 series sound level meter (SLM) set at the slow response mode with A-weighted decibels $[\mathrm{dB}(\mathrm{A})]$. Noise measurements were conducted between 1:002:00 pm which is the break period for children to play, and a classroom in each of the schools was randomly selected for the study. Measurements were conducted at two points in both the classrooms and school playgrounds and data is presented as mean noise level $[\mathrm{dB}(\mathrm{A})]$.

\section{RESULTS}

The noise levels of classrooms and playgrounds of the schools selected for this study were in the range of 78-92 dB(A) and 61-97 $\mathrm{dB}(\mathrm{A})$ respectively (Figures 1 and 2).

Of the primary schools investigated, the highest noise levels were reported for UNIZIK Nursery/Primary School with values of $92 \mathrm{~dB}(\mathrm{~A})$ and $95 \mathrm{~dB}(\mathrm{~A})$ respectively for the classroom and playground. Whereas, lowest noise levels were recorded for Holy Innocent Primary School with values of $78 \mathrm{~dB}(\mathrm{~A})$ and $79 \mathrm{~dB}(\mathrm{~A})$ respectively for the classroom and playground (Figure 1).

In Secondary School category, Maria Regina Comprehensive Secondary School presented the highest noise levels of 89 and $97 \mathrm{~dB}(\mathrm{~A})$ respectively for the classroom and playground. While lowest noise levels of 83 and $61 \mathrm{~dB}(\mathrm{~A})$ respectively for the classroom and playground respectively was recorded for St. Philip's Anglican Grammar School (Figure 2).

\section{DISCUSSIONS}

Noise levels are measured in decibels $(\mathrm{dB})$ which is a logarithmic mode of quantifying sound loudness, intensity and pressure. One decibel is the threshold of hearing. Approximately $60 \mathrm{~dB}$ is the level of normal talking. The Aweighted variety of sound wave measurement is used for the quantification of the environmental noise in $\mathrm{dB}(\mathrm{A})$ units. The sound level meter or sound meter, an instrument that measures sound pressure level, is commonly used in noise pollution studies for the quantification of different classes of noise (Ana et al., 2009; Ibekwe et al., 2016).

The classroom environments are usually filled with factors which does not only disrupt the child's ability to listen and learn but also subject the children to emotional and behavioral stress (Owojori et al., 2017). For much of the day in a primary school classroom, young children are exposed to the noise of other children producing "classroom babble" at levels typically of around $65 \mathrm{~dB}(\mathrm{~A})$, while the typical overall exposure level of 
- Good Shepherd Secondary School

घt. Joseph's Secondary School
- Maria Regina Comprehensive Secondary School

- St. Philip's Anglican Grammar School

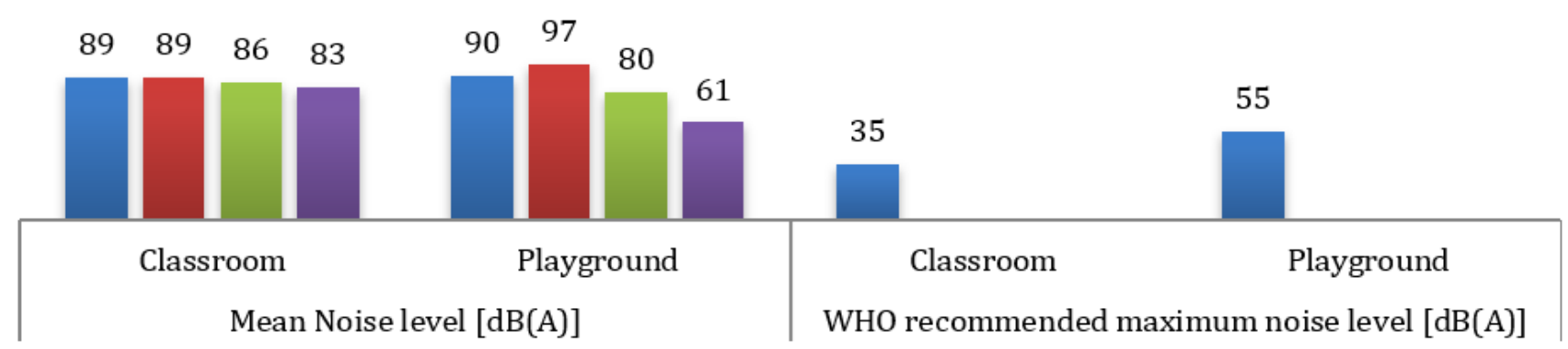

Figure 2. Mean Noise levels $[(\mathrm{dB}) \mathrm{A}]$ of classrooms and playgrounds of the selected secondary schools in Otolo-Nnewi

a child at primary school has been estimated at around 72 $\mathrm{dB}(\mathrm{A})$. Also, schools may be exposed to high levels of environmental noise, particularly in urban areas from sources such as road traffic, trains, aircraft, and construction noise (Shield and Dockrell, 2008; Shield and Dockrell, 2004).

Results of our study reveal that the noise levels of classrooms and playgrounds in the selected schools in Nnewi were significantly above the WHO's recommended maximum noise levels which are 35 and $55 \mathrm{~dB}(\mathrm{~A})$ for classrooms and playgrounds respectively (Amir et al., 2017; Berglund et al., 1999). Of the various factors that may be responsible for these schools' high classroom noise levels, as well as most other Nigerian schools and learning institutions, lack of or poor acoustics in the classroom contributes significantly to this issue. According to Chan et al. (2015), the reduction of classroom background noises including external noise (like traffic noise) and internal noise (for example, noise resulting from students running in corridors or talking in the classroom or adjacent classrooms) can be achieved by implementing acoustic modifications to the classrooms. These modifications include installation of double-glazing and solid concrete barriers to eliminate external noise, as well as the installation of carpets, ceiling tiles, acoustically treated furniture and/or curtains to reduce internal noises (Chan et al., 2015).

According to the WHO, the critical health effects of noise pollution in schools include speech interference, disturbance of information extraction (e.g. comprehension and reading acquisition), message communication and annoyance (Berglund et al., 1999). Also, it has been shown that there is significant drop in children's performance, particularly in learning to read, when the background noise level interferes with speech (Shield and Dockrell, 2004, 2008).

In less developed countries (LDCs) where urban laws and proper land use conditions either do not exist or are not always monitored and enforced, few locale-specific data exist to help improve the situation (Ana et al., 2009). According to Ibekwe et al. (2016), many of these countries do not have regulations/legislation on noise pollution due to lack of the political will or the insight into the deleterious effect on environmental life and the ecosystem. The associated difficulty in defining, evaluating and devising control measures for environmental noise has been highlighted as a strong militating factor towards an effective control of noise pollution (Ibekwe et al., 2016; Osagie et al., 2018).
In Nigeria, the National Environmental Standards and Regulations Enforcement Agency's (NESREA) published a document specifying the maximum permissible noise levels for the Nigerian environment including buildings used academic learning (NESREA, 2009). However, the proliferation of noise pollution in schools and the general environment reflects the lack of political will or no legal framework upon which these regulations are enforced towards the control of noise pollution. Majority of the public/environmental health officers whose duty includes ensuring public health and safety by routinely monitoring noise levels and other hazards in the environment, including the school environment, tend to be unaware of their roles in schools and learning institutions. According to Owojori et al. (2017) noise has not been considered by Nigerian people as an insidious pollutant or being attributed to any physiological impacts. Also, Olayinka (2013) stated that the Nigerian Government and her citizenry appear not to be conscious of the present and future impacts of noise induced health hazards in their environment.

\section{CONCLUSION}

This study reveals the high noise levels in primary and secondary schools in Otolo-Nnewi, Anambra State Nigeria. These noise levels were significantly above the World Health Organization's recommended classroom and outdoor/playground noise levels. This study highlights the negative health and academic implications of noise in schools and institutions of learning and such public health implications of noise as observed in this study could contribute to psychological dysfunctions (noise annoyance) followed by sleep disturbances and dementia.

\section{Recommendations}

Therefore, it is important for the school management to reduce the noise level by controlling the activities of school children during break period in both classroom and playground.

Also, periodic auditory and general health examination should be carried out for individuals in the studied schools within the state and beyond. 


\section{ACKNOWLEDGEMENTS}

We wish to acknowledge the Head of Primary Schools in Otolo-Nnewi, Anambra State, Nigeria for the immense support.

\section{REFERENCES}

Amir, H. N, Soheila, L., Reza, R., Reza, S. and Shahla, L. (2017). Assessment the noise level in libraries and dormitories of Kermanshah University of Medical Sciences in 2016 (Kermanshah, Iran). Fresenius Environmental Bulletin.

Ana, G., Shendell, D., Brown, G. and Sridhar, M. (2009). Assessment of Noise and Associated Health Impacts at Selected Secondary Schools in Ibadan, Nigeria. Journal of Environmental and Public Health, Article ID 739502. https://doi.org/10.1155/2009/739502

Berglund, B., Lindvall, T., Schwela, D. H. and World Health Organization. (1999). Guidelines for Community Noise. World Health Organization Geneva. Available at: https://apps.who.int/iris

Chan, K. M., Li, C. M., Ma, E. P., You, E. M. and McPherson, B. (2015). Noise levels in an urban Asian school environment. Noise Health, 17(74), 48-55. https://doi.org/10.4103/14631741.149580

Elufioye, A. (2017). Nigeria-Erosion and Watershed Management Project: Environmental Assessment (Vol. 36): Environmental and social management plan for Nnewichi gully erosion site, Nnewi North LGA, Anambra State. Report Number SFG1692.

Ibekwe, T., Folorunso, D., Ebuta, A., Amodu, J., Nwegbu, M., Mairami, Z. ... Nwaorgu, O. (2016). Evaluation of the environmental noise levels in Abuja municipality using mobile phones. Ann Ib Postgrad Med, 14(2), 58-64.
NESREA. (2009). National Environmental (Noise Standards and Control) Regulations. National Environmental Standards and Regulations Enforcement Agency (NESREA). Printed and Published by The Federal Government Printer, Lagos, Nigeria. FGP 1121102009/1,000 (0L60), 17. Available at: http://extwprlegs1.fao.org/docs/pdf/nig146077.pdf

Nnebue, C. C., Ebenebe, U. E., Duru C. B., Egenti N. B., Emelumadu O. F and Ibeh C. C. (2010). Availability and continuity of care for maternal health services in the primary health centres in Nnewi, Nigeria. International Journal of Preventive Medicine, 7(1), 44. https://doi.org/10.4103/2008-7802.177885

Olayinka, O. S. (2013). Effective Noise Control Measures and Sustainable Development in Nigeria. World Journal of Environmental Engineering, 1(1), 5-15.

Osagie, I., Tenebe, I. T., Emenike, P. C., Adesina, O. S., Okougha, A. F. and Aitanke, F. O. (2018). Assessment of noise-levels of generator-sets in seven cities of SouthSouthern Nigeria. African Journal of Science, Technology, Innovation and Development, 10(2), 125-135. https://doi.org/10.1080/20421338.2017.1400711

Owojori, A. A., Gadzama, I. M. K. and Sow, G. J. (2017). Acoustic Indoor Noise Level of Unoccupied Classrooms in Selected Schools in Zaria Metropolis, Nigeria. Journal of Health and Environmental Studies, 1(1\&2), 1-9.

Shield, B. M. and Dockrell, J. E. (2003). The Effects of Noise on Children at School: A Review. Journal of Building Acoustics 10(2), 97-106. https://doi.org/10.1260/135101003768965960

Shield, B. M. and Dockrell, J. E. (2004). External and internal noise surveys of London primary schools. The Journal of the $\begin{array}{lll}\text { Acoustical } & \text { Society, } & \text { 115(2), }\end{array}$ https://doi.org/10.1121/1.1635837

Shield, B. M. and Dockrell, J. E. (2008). The effects of environmental and classroom noise on the academic attainments of primary school children. The Journal of the Acoustical Society of America, 123(1), 133-144. https://doi.org/10.1121/1.2812596 